\title{
Inflatin Targeting Framework (ITF) and Indonesia Stable Market Index
}

\author{
Iman Lubis ${ }^{1}$, Syamruddin ${ }^{2}$, Eni Puji Astuti ${ }^{3}$, and Amipriyadi Gerha Pemana ${ }^{4}$ \\ \{dosen01479@unpam.ac.id ${ }^{1}$,dosen01343@unpam.ac.id ${ }^{2}$,dosen00807@unpam.ac.id ${ }^{3}$, \\ ami035@univpancasila.ac.id ${ }^{4}$ \} \\ University of Pamulang ${ }^{1}$, Tangerang Selatan ${ }^{1}$, University of Pamulang ${ }^{2}$, Tangerang Selatan ${ }^{2}$, University \\ of Pamulang, Tangerang Selatan ${ }^{3}$ and University of Pancasila ${ }^{4}$, Jakarta Selatan ${ }^{4}$
}

\begin{abstract}
The objective is linking the monetary policy to stable price indexes market in Indonesia. The monetary policies are BI rate (BI rate 7 days Repo) and Inflation. Meanwhile, Stable price market indexes are FTSE Indonesia, 30 Index, Development Board Index, Miscellaneous Index, Sharia Index, and LQ-45 Index. The method is used Markov Switching 2 Regimes. The data are monthly 5 years behind from March 2015 to February 2020. The results are that only can inflation negatively affect bearish markets and can BI rate negatively influence bullish markets.
\end{abstract}

Keywords: Markov Switching Regime; Stable Price; and Index Market;

\section{Introduction}

Bank Indonesia has the objective to achieve and maintain the stability of the value of the rupiah. This goal as stated in Law No. 23 of 1999 concerning Bank Indonesia, as amended by Law No. 3 of 2004 and Law No. 6 of 2009 in article 7. The stability of the rupiah referred to has two dimensions. The first dimension of the stability of the value of the rupiah is the stability of the prices of goods and services reflected in the development of the inflation rate. Meanwhile, the second dimension is related to the development of the rupiah exchange rate against other countries' currencies.

In an effort to achieve these goals, Bank Indonesia has adopted the Inflation Targeting Framework (ITF) monetary policy framework since July 1, 2005. In this framework, inflation is an overriding objective. Bank Indonesia consistently continues to make various improvements to the monetary policy framework, in accordance with changes in dynamics and economic challenges that occur, in order to strengthen its effectiveness (1).

In implementing monetary policy, Bank Indonesia adopted a framework called the Inflation Targeting Framework (ITF) with the use of interest rates as operational targets. This framework has been formally applied since July 1, 2005, after previously using monetary policy that applies base money (base money) as the target of monetary policy.

In Indonesia stock market, there are 6 market indexes that are stability markets that have bullish market and bear market. The others are volatility market classification (2). It is supported by another research such as, in Turkey, monetary policy is more effective in bull market periods. It seems that discretionary policy has no a good impact in bearish market 
periods (3). From those, researchers want to associate between the monetary policies such as $\mathrm{BI}$ rate and Inflation and stability market index that can be divided bearish and bull markets.

\section{Literature Review}

Several studies have discussed about the relationship between monetary policy and stock market return. In the long run, the interest rates have relationship to stock returns (4) (5), (6).; interest rates increase one percent will decrease stock market return $12.3459 \%$ (7). In 40 countries, interest rates significantly affect stock returns in developed economies within fallen interest rates (8). The large alterations in monetary and fiscal policies have strong relationship to stock market returns (9), (10).. Interest rate increase and exchange rate depreciation in China have induced market down (11). In Turkey, when stock market during bull market and bear market monetary policy rate has affected in bull market (3). Central banking policies in emerging countries have affected in financial market performance depending on the policymakers (12). Monetary policies increase expected returns and actual returns (13). Shortterm seems to be relevant to explain several dimensions regarding equity risk premia (14)

Stock price majorly lead inflation in France, Germany, Belgium, Netherlands, and Portugal and lead industrial production in the four countries that both of them have a positive correlation. Inflation can be important factor to be predictive and the tools of policy makers using probit model (15). Inflation, default spread yield, and the term spread are useful in forecasting bear market, in particular default yield spread that can predict three month ahead (16). The major determinations of risk premium are vacancy rate, The FTSE 100, new monetary index and autoregressive parameter (17). US monetary policy has affected international output, equity prices, and exchange rates against US (18).

However, there were several researches that found that Monetary policy easing not correlate to stock market but it correlates to exchange rate (19) when the macro condition has problem (Echekoba, Ananwude, \& Lateef, 2018); interest rate correlate to bonds for emerging economies (20), and sharia monetary.correlate to sharia index (21) and asymmetry is hypotheses to connect . (22).

Stock market can be clearly more explained by market-frictions and sentiment's investor rather than fundamental value (23), (24). Contrary, when co-movement has been revisited there is no longer any meaningful evidence from either an economic or statistical standpoint (25), such as paying-dividend stocks (26).

Monetary policies have not connected to firm-level stock returns (27), slower to small stocks (28), but those connected to investable firms (29), asset bubbles in housing (30), aggregate earnings (31), bank's stock price (32),. Volatility on that day when quantitative easing is announced (33).

Investor chose the stock based on price (34). It generates lottery-like stocks (35). In the Eurozone, fund investors allocate their portfolio investment from money market into riskier equity market (36).

Unfortunately, the others have found that the impacts of monetary policies on asset prices be biases because many variables react to them. The findings contain the estimated effects on stock prices emerge too small and those on Treasury Yields too large (37). Also, unexpected reserve ratio made market overreacting but the expected reserve ratio change made market underreacting (38). 


\section{Methods}

Data are secondary data from www.bi.go.id and www.investing.com. Monetary policies are used BI rate and Inflation (Consumer Price Index). Index Markets are FTSE Index, Index 30, Development Board Index, Miscellaneous Index, Liquid 45 Index, and Sharia Index. The data are monthly from March 2015 to February 2020. It uses data level that is not stationer. X1 is inflation ate and X2 is BI Rate. Meanwhile Y1, Y2, Y3, Y4, Y5 and Y6 are FTSE Index, Index 30, Development Board Index, Miscellaneous Index, Liquid 45 Index, and Sharia Index. Estimated Equation are:

$$
\begin{aligned}
& \text { State } 1 \\
& \mathrm{Y}=\mathrm{C}(1)+\mathrm{C}(2) * \mathrm{X} 1+\mathrm{C}(3) * \mathrm{X} 2 \\
& \text { State } 2 \\
& \mathrm{Y}=\mathrm{C}(4)+\mathrm{C}(5) * \mathrm{X} 1+\mathrm{C}(6) * \mathrm{X} 2 \\
& \mathrm{SIGMA}=@ \operatorname{EXP}(\mathrm{C}(7)
\end{aligned}
$$

Unconditional Probability is

$$
\begin{gathered}
\text { Unconditional Probability }(t)= \\
p\left(S_{t}=x \mid \text { all known information known at time } t\right) x=1 \text { (bearish)or } x= \\
2(\text { bullish }) \text { Where } \mu_{2}<\mu_{1}
\end{gathered}
$$

The method of segmentation bullish-bearish is markov switching model that is formulated by Hamilton (1989) as:

$$
\mathrm{Y}_{\mathrm{t}}=\mu_{\mathrm{st}}+\mathrm{e}_{\mathrm{t}}, \mathrm{e}_{\mathrm{t}} \sim \mathrm{N}\left(0, \sigma_{\mathrm{st}}{ }^{2}\right)
$$

Transition Probability use

$$
\left[\begin{array}{ccc}
p_{11} & \ldots & p_{M 1} \\
\vdots & \ddots & \vdots \\
p_{1 M} & \ldots & p_{M M}
\end{array}\right]
$$

The Probability of Functional Transition is written equation by:

$$
P_{i j}=\frac{p_{i j}^{2}}{1+p_{i j}^{2}}
$$

The expected duration of state $\mathrm{j}$ can be written where $\mathrm{i}=$ state $\mathrm{i}, \mathrm{j}=$ state $\mathrm{j}$, as follow:

$$
E(D)=\frac{1}{1-P_{i j}}
$$

\section{Results and Discussion}

We find that monetary policies influence market indexes that are stability in Indonesia with different regimes. First, Inflation has affected FTSE, IDX 30, Development Board Index, Sharia Index and Liquid 45 Index in bearish. The expected durations of FTSE, IDX 30, Development Board Index, Sharia Index and Liquid 45 indexes are affected when bearish occur are 48.01470 months, 45.83930 months, 54.63640 months, 13 months, and 
44.93446 months. Second, BI rate inversely influence from Inflation. BI rate affects the bullish markets. BI rate affects FTSE, IDX 30, Development Board Index, Sharia Index and Liquid 45 Index in bullish markets except Miscellaneous Index that is influenced in bearish market by BI rate. The durations of those are 16.07261 months, 15.88598 months, 34.61814 months, 36.70339 months, and 15.96429 months, and 12.43526 months.

When market bearish takes place inflation is the best way to increase price market index. The effect of inflation negatively influences. If the bearish occur the effect inflation can predict duration from 13 months to 48 months at 5 indexes mentioned. Bank Indonesia must stay the inflation low so that the price market index does not sink too deep. When bullish market occurs the BI rate can support it through low interest. If the bullish occurs the effect of BI rate can have the expected duration from 12.43256 months to 36.70339 months. Bank Indonesia must decrease the interest rates so that the price market indexes can continue in bullish market.

\section{Conclusion}

To conclude, interest rates cannot affect price indexes stable market in bearish and bullish. It can only influence in bullish market and it loses its power in bearish market. Only can inflation manipulate price indexes market retaining bearish markets. We discover BI rate and inflation cannot affect to whole times and only in data level which means short impact for the movement of price market.

\section{References}

[1] Bank Indonesia. Bank Indonesia Website. [Online] July 31, 2019. [Cited: September 02, 2019.] https://www.bi.go.id/id/moneter/tujuan-kebijakan/Contents/Default.aspx.

[2] Pendekatan Markov Switching pada Pasar Modal Indonesia. Lubis, Iman. 2, 2018, Jurnal Madani, Vol. 1, pp. 417-429.

[3] The impact of monetary policy on stock returns during bull and bear markets: The evidence from Turkey. Atis, A G and Deniz, E R E R. 4, 2018, Ege Akademik Bakis Dergisi, Vol. 18, pp. 699-710.

[4] Dichotomous stock market reaction to episodes of rules and discretion in the US monetary policy. Marinescu, I I, Horobet, A and Lupu, R. 2018, Economic Modelling, Vol. 70, pp. 5666.

[5] The impact of monetary and fiscal policy shocks on stock mrkets: Evidence from China. Hu, L, Han, J and Zhang, Q. 8, 2018, Emerging Markets Finance and Trade, Vol. 54, pp. 1856-1871.

[6] The quantitative easing effect on stock market of the USA, the UK and Japan: An ARDL approach for the crisis period. Lima, L, et al., et al. 6, 2016, Journal of Economic Studies, Vol. 43, pp. 1006-1021.

[7] Interest rates volatility and its consequences on stock returns: The case study from Amman Stock Exchange, Jordan. Aljarayesh, N I A, Asfour, L K and Al-Abdallah, S Y. 2, 2018, Journal of Economics Library, Vol. 5, pp. 149-160.

[8] Stock returns and interest rates around the World. Assefa, T A, Esquedsa, O A and Mollick, A V. 2017, Journal of Economics and Business, Vol. 89, pp. 20-35.

[9] The effect of fiscal and monetary policies interaction on stock market performance: Evidence from Nigeria. Lawal, A I, et al., et al. 1, 2018, Future Business Journal, Vol. 4, pp. 16-33.

[10] How does the Thai stock market respond to monetary and fiscal policy shocks? Prukumpai, S and Sethapramote, Y. 2, 2019, DLSU Business \& Economics Review, Vol. 28, pp. 52-68. 
[11] Monetary Policy, exchange rate fluctuation and herding behavior in the stock market. Gong, $\mathrm{P}$ and Dai, J. 2017, Journal of Business Research, Vol. 76, pp. 33-43.

[12] Can central banking policies make a difference in financial market performance in Emerging Countries? The case of India. Sharma, G D, Mahendru, M and Srivastava, M. 2, 2019, Economies, Vol. 7, p. 49.

[13] On stock market returns and monetary policy. Thorbecke, W. 2, 1997, The Journal of Finance, Vol. 52, pp. 635-654.

[14] Short-term interest rates and stock market anomalies. Maio, P and Santa-Clara, P. 3, 2017, Jornal of Financial and Quantitative Analysis, Vol. 52, pp. 927-961.

[15] Asset Pricing regime-switching and the role of inflation targeting monetary policy. Chatziantoniou, I, Filis, G and Floros, C. 2017, Global Finance Journal, Vol. 32, pp. 97-112.

[16] Further evidence on bear market predictability: The role of the external finance premium. Chen, N K, Chen, S S and Chou, Y H. 2017, International Review of Economics \& Finance, Vol. 50, pp. 106-121.

[17] International money supply and real estate risk premium: The case of the London office market. Coen, A, Lefebvre, B and Simon, A. 2018, Journal of International Money and Finance, Vol. 82, pp. 120-140.

[18] Spillovers from US monetary policy: evidence from a time varying parameter global vector auto-regressive model. Crespo Cuaresma, J, et al., et al. 2019, Journal of the Royal Statistical Society: Series A (Statistics in Society).

[19] Testing for the causality between interest rate and stock market peformance in Nigeria. Amassoma, D and Adeleke, O. 3, 2018, Economic Studies, Vol. 27.

[20] Determining the effects of monetary policies on capital markets of the emerging economies: An evidence from E7 countries. The Impacts of Monetary Policy in the 21st Century: Perspectives from Emerging Economies. Dincer, H, Yuksel, S and Adali, Z. 2019, Emerald Publishing Limited, p. 16.

[21] Dual monetary instruments' impact on the performance and stability of Jakarta Islamic Index. Azizi, B A. 2, 2018, Journal of Islamic Monetary Economics and Finance, Vol. 3, pp. 315-348.

[22] Asymmetric Effects of Macroeconomic shocks on the Stock Returns of the G-7 countries: The evidence from the NARDL Approach. Erdogan, L and Tiryaki, A. 1, 2018, Journal of CUrrent Researches on Business and Economics, Vol. 8, pp. 119-146.

[23] Comovement. Barberis, N, Shleifer, A and Wurgler, J. 2, 2005, Journal of Financial Economics, Vol. 75, pp. 283-317.

[24] High frequency trading and comovement in financial markets. Malceniece, L, Malcenieks, K and Putnins, T J. 2019, Journal of Financial Economics.

[25] Comovement revisited. Chen, H, Singal, V and Whitelaw, R F. 3, 2016, Journal of Financial Economics, Vol. 121, pp. 624-644.

[26] Preference for dividends and return comovement. Hameed, A and Xie, J. 1, 2019, Journal of Financial Economics, Vol. 132, pp. 103-125.

[27] Monetary policy suprises and firm-level stock return predictability: evidence from a new panel-based approach. Floro, D. 17, 2018, Applied Economic Letters, Vol. 25, pp. 1255-1260.

[28] Monetary policy and stock valuation: strctural VAR identification and size effects. Kontokinas, A and Zekaite, Z. 5, 2018, Quantitative Finance, Vol. 18, pp. 837-848.

[29] Do foreign investor insulate firmsfrom local shocks? Evidence from the response of investable firms to monetary policy. Francis, B B, Hunter, D M and Kelly, P J. 2017.

[30] The effects of monetary policy on stock market bubbles: Some evidence. Gali , J and Gambetti, L. 1, 2015, American Economic Journal: Macroeconomics, Vol. 7, pp. 233-257.

[31] Aggregate earnings surprises, monetary policy, and stock returns. Gallo, L A, Han, R N and Li, C. 1, 2016, Journal of Accounting and Economics, Vol. 62, pp. 103-120.

[32] Monetary policy and bank profitability in a low interest rate environment. Altavilla, C, Boucinha, M and Peydro, J L. 96, 2018, Economic Policy, Vol. 33, pp. 531-586. 
[33] Central bank announcements and realized volatility of stock market in $G 7$ countries. Lyocsa, S, Molnar, p and Plihal, T. 2019, Journal of International Financial Markets, Institutions and Money, Vol. 58, pp. 117-135.

[34] Price-based return comovement. Green, T and Hwang, B H. 1, 2009, Journal of Financial Economics, Vol. 93, pp. 37-50.

[35] Gambling and comovement. Kumar, A, Page, J K and Spalt, O G. 1, 2016, Journal of Financial and Quantitative Analysis, Vol. 51, pp. 85-111.

[36] Asset allocation and monetary policy: Evidence from the eurozone. Hau, H and Lai, S. 2, 2016, Journal of Financial Economics, Vol. 120, pp. 309-329.

[37] The impact of monetary policy on asset prices. Rigobon, R and Sack, B. 8, 2004, Journal of Monetary Economics, Vol. 51, pp. 1553-1575.

[38] How does reserve ratio decreasing act on market: Empirical evidence from China. Wang, Y. 5, 2019, Journal of Applied Finance and Banking, Vol. 9, pp. 15-25.

[39] Do stock markets lead or lag macroeconomic variables? Evidence from Select European countries. Camilleri, S J, Scicluna, N and Bai , Y. 2019, The North American Journal of Economics and Finance, Vol. 48, pp. 170-186.

[40] Effect of Monetary Policy on the Performance of the Nigerian Capital Market (1986-2016): Stylized Facts from ARDL Approach. Echekoba, F, Ananwude, A and Lateef, O. 6, 2018, Advances in Research, Vol. 14, pp. 1-15.

[41] Stock market reaction to monetary policy: An event study analysis of the Bralizian case. Val, F D F, et al., et al. 11, 2018, Emerging Market FInance and Trade, Vol. 54, pp. 2577-2595.

[42] Do stock markets lead or lag macroeconomic variables? Evidence from Select European Countries. Silvio, et al., et al. 2019.

[43] Asymmetric effects of Chinas monetary policy on the stock market: Evidence from a nonlinear VAR mode. Sun, Y and Wang, X. 6, 2018, Asian Economic and Financial Review, Vol. 8, pp. 745-761.

[44] When no news is good news-The decrease in investor fear after the FOMC announcement. Fernandez-Perez, A, Frijns, B and Tourani-Rad, A. 2017, Journal of Empirical Finance, Vol. 41, pp. 187-199.

[45] Volatility spilover effects in leading cryptocurrencies: A BEKK-MGARCH analysis. Katsiampa, P, Corbet, S and Lucey, B. 2019, Finance Research Leters, Vol. 29, pp. 68-74.

[46] Kementrian Perdagangan Republik Indonesia. Kemendag website. [Online] [Cited: 08 28, 2019.] https://www.kemendag.go.id/id/economic-profile/economic-indicators/amount-ofcirculate-money.

[47] Kementrian Perdagangan Republik Indonesia. Kemendag Website. [Online] [Cited: 08 28, 2019.] https://www.kemendag.go.id/id/economic-profile/economic-indicators/inflation.

[48] Kementrian Perdagangan Republik Indonesia. Kemendag Website. [Online] [Cited: 08 28, 2019.] https://www.kemendag.go.id/id/economic-profile/economic-indicators/exchanges-rates.

[49] Kementrian Perdagangan Republik Indonesia. Kemendag Website. [Online] [Cited: 08 28, 2019.] https://www.kemendag.go.id/id/economic-profile/economic-indicators/export-import.

[50] Fusion Media Limited. Investing.com. Investing Website. [Online] [Cited: February 29, 2020.] https://www.investing.com/indices/idx-shariah.

[51] Fushion Mesdia Limited. Investing.com. Investing Website. [Online] [Cited: February 29, 2020.] https://www.investing.com/indices/idx-miscellaneous-industry.

[52] Fushion Media Limited. Investing.com. Investing Website. [Online] [Cited: February 29, 2020.] https://www.investing.com/indices/idx-development.

[53] - Investing.com. Investing Website. [Online] [Cited: February 29, 2020.] https://www.investing.com/indices/jakarta-lq45.

[54] -. Investing.com. Investing Website. [Online] [Cited: February 29, 2020.] https://www.investing.com/indices/ftse-indonesia.

[55] Badsan Pusat Statistik. Bada Pusat Statistik. Badan Pusat Statistik Website. [Online] [Cited: February 29, 2020.] https://www.bps.go.id/dynamuctable/2015/12/22/1061/bi-rate-20052018.html. 
[56] Bank Indonesia. Bank Indonesia. Bank Indonesia Website. [Online] [Cited: February 29, 2020.] https://www.bi.go.id/id/moneter/bi-7day-RR/data/Contents/Default.aspx.

[57] - . Bank Indonesia. Bank Indonesia Website. [Online] [Cited: February 29, 2020.] https://www.bi.go.id/id/moneter/inflasi/data/Default.aspx.

[58] A new approach to the economic analysis of nonstasionary time series and business cycle. Hamilton, James D. 1989, Econometrica, Vol. 57, pp. 357-384. 